\title{
Walter Bernardi
}

\section{The Controversy on Animal Electricity in Eighteenth-Century Italy: Galvani, Volta and Others}

As is well known, Luigi Galvani was not the first to use the electric spark over the muscles of alive or dead animals and to discuss the existence of "animal electricity". The hypothesis of an animal electricity, or, as it was called in the 18th century, of a "neuro-electric fluid" which flowed in the nerves and caused contraction of the muscles, was not at all a novelty. ${ }^{1}$ But, on September 20, 1786, Galvani made a crucial experiment when he proved that a dead and "prepared" frog jumped without an external electric source, just by touching muscles and nerves with a metallic arc. ${ }^{2}$

The frog functioned as a Leyden jar; it was an electric engine. Galvani made a breakthrough that was judged revolutionary by all the scientists of his time. He had changed a previous speculative hypothesis, which looked like the medical quackery of Mesmer's animal magnetism, into an experimental theory with important

\footnotetext{
${ }^{1}$ A traditional, copious bibliography exists about the forerunners of Galvani. See H.E. HOFF, "Galvani and the Pre-Galvanian Electrophysiologists", Annals of Science, 1 (1936), pp. 157-72; W.C. WALKER, "Animal Electricity before Galvani”, Annals of Science, 2 (1937), pp. 84-113; C.G. PUPILLI and E. FADIGA, "The Origins of Electrophysiology", Journal of World History, 7 (1963), pp. 547-89; N. KIPNIS, "Luigi Galvani and the Debate on Animal Electricity", 1791-1800, Annals of Science, 44 (1987), pp. 107-42; J.L. HEILBRON, "The contributions of Bologna to Galvanism", Historical Studies in the Physical and Biological Sciences, 22 (1991), pp. 57-85; M. PerA, The Ambiguous Frog: The Galvani-Volta Controversy on Animal Electricity, (Princeton, 1992) (trans. of La rana ambigua: La controversia sull'elettricità animale tra Galvani e Volta, (Torino, 1986). Among the scientists who were interested in the subject of animal electricity before Galvani the most famous are the Frenchman Nicolas Bertholon and the Italian Giuseppe Gardini. In 1780 Bertholon had already spoken of an "animal electricity" and of a "human electricity". See N. BERTHOLOn, De l'électricité du corps humain dans l'état de santé et de maladie, (Paris, Lyon, 1786), pp. xii, xix. In the same years of Galvani, Gardini had recourse to "a spontaneous electricity of animals and of men". See G. GARDINI, De electrici ignis natura dissertatio regiae scientiarum et literarum academiae mantuanae exibita anno 1780, ab eademque probata, (Mantuae, 1792), pp. $22,159-60$.

${ }^{2}$ See Memorie ed esperimenti inediti di Luigi Galvani con una iconografia di lui ed un saggio di bibliografia degli scritti, (Bologna, 1937), p. 397.
} 
physiological consequences. For this reason, in spite of Galvani's numerous forerunners, nobody disputed his title as "father of animal electricity".

Galvani published his discovery in a 53-page Latin paper, which was included in the seventh volume of the Commentarii of the Bologna Academy of Sciences. ${ }^{3}$ When was Galvani's Commentarius printed? The publishing date of his masterpiece, which is also the date of the birth of electrodynamics and electrophysiology, has always been a mystery to historians. ${ }^{4}$ Now, the examination of Sebastiano Canterzani's manuscript correspondence in the University Library of Bologna allows us to solve the problem. The seventh volume of the Commentarii was dated 1791 and the imprimatur had been awarded on March 27, but it was published at the beginning of 1792, perhaps on January 2 or 3 . During the delay of the printing of the Commentarii Galvani had supplied for printing some abstracts of his paper that were given to many friends in Bologna and elsewhere in Italy.

The news of Galvani's discovery caused great feeling in scientific circles and it produced a repercussion among physicians and the merely curious: astonishment, wonder and immediate resolution to repeat Galvani's experiments, with the obvious consequence that frogs were decimated in great quantities everywhere, first in Italy and then in Europe. The atmosphere of this moment is well shown by a letter from Bernardino Ferrari to Sebastiano Canterzani dated September 14. Writing from Milan he said:

Now here the experiments are also repeated in ladies' salons, and they furnish a good spectacle to all. ${ }^{5}$

Some months later, on March 16, 1793, Leopoldo Caldani wrote to Lazzaro Spallanzani that animal electricity had became "a fashionable matter". ${ }^{6}$

Between 1791 and 1800, in the ten years from the publication of Galvani's Commentarius to the invention of the electric pile by Alessandro Volta, a scientific revolution occurred in Europe. It was not only a scientific controversy. The political problems and revolutionary events which at the end of the 18th century changed French and Italian life had a close relationship with the development and conclusion of the controversy between Galvani and Volta. It is enough to consider the political personality of the two protagonists in order to understand this. Galvani was a man of the Ancien Régime, who always opposed revolutionary and republican ideas. An exemplary action dramatically marked his life. On April 20, 1798, he refused to take the oath to the Cisalpine Republic because the way seemed to be a declaration

3 L. GALVANI, "De viribus electricitatis in motu musculari Commentarius", De bononiensi scientiarum et artium instituto atque academia Commentarii, (Bononiae), 7 (1791), pp. 363-418.

${ }^{4}$ See. J.F. FUlton and H. CUSHING, "A Bibliographical Study on the Galvani and the Aldini Writings on Animal Electricity", Annals of Science, 1 (1936), p. 244.

${ }^{5}$ Bologna, University Library, Letters to Sebastiano Canterzani, Ms. 2096, Buste IV-V.

${ }^{6}$ L. SPallanZani, Edizione Nazionale delle Opere, Parte prima, Carteggi, P. DI PIETRO, ed., (Modena, 1980-94), III, p. 273. 
against the Catholic religion. In Pavia not only Volta, but also even a Catholic priest like Spallanzani swore the same oath. In consequence of his action Galvani lost his chair at Bologna University and died in poverty. On the contrary, Volta embraced the cause of political revolution, even if he remained a moderate and he engaged himself in the French government of Lombardy. In exchange Napoleon granted him great honours and elected him senator of the Kingdom of Italy.

The bibliography on animal electricity is now very extensive, even if we are still lacking definite, reliable editions of Galvani's and Volta's works and manuscripts. ${ }^{7}$ But the true historical problems concern the form of the controversy itself. Indeed, many historians and philosophers of science continue to look at the controversy from the point of view of Volta's paradigm, that is from our privileged standpoint, forgetting that Galvani and Volta found two different things and victory in the controversy, as I.B. Cohen has said, was not "Volta's, but rather Volta's and Galvani's jointly". Today it is no longer possible to reduce the controversy on animal electricity to the Galvani-Volta controversy, since different and separate controversies on Galvani's discovery followed in Italy at the end of the 18th century. For this reason, besides carefully examining the Galvani-Volta relationship, historians should carefully examine the works, papers and manuscripts of the scientists operating in Pavia such as Luigi Valentino Brugnatelli, Jacopo Rezia, Eusebio Valli, Vincenzo Malacarne, Bassiano Carminati, Giuseppe Mangili, Antonio Scarpa, Giovanni Battista Presciani, Carlo Barletti, Lazzaro Spallanzani, as well as of other authors who lived elsewhere in Italy: Anton Maria Vassalli, Carlo Giulio, Francesco Rossi and Luigi Rolando in Turin; Sebastiano Canterzani, Germano Azzoguidi, Tarsizio Riviera and Giovanni Aldini in Bologna; Giambattista Venturi in Modena; Leopoldo and Floriano Caldani, Stefano Gallini, Giuseppe Olivi, and Simone Stratico in Padua, Felice Fontana, Giovanni Fabbroni and Giovacchino Carradori in Florence, Vincenzo Dandolo in Venice, Francesco and Leopoldo Vaccà Berlinghieri in Pisa; Pietro Moscati, Pierre Thouvenel and Carlo Amoretti in Milan. ${ }^{9}$

The first thing which should be noted is that the controversy on animal electricity did not start in Pavia, but in Bologna. Usually it is said that the controversy started in Pavia in May 1792 with Volta's intervention. On the contrary, before the first

${ }^{7}$ For a general discussion of the international bibliography on animal electricity see W. BERNARDI, I fluidi della vita: Alle origini della controversia sull'elettricità animale, (Firenze, 1992), pp. 1748.

${ }^{8}$ See L. Galvani, Commentary on the Effects of Electricity on Muscular Motion, I.B. COHEN, introd. and notes, M. GLOVER FOLEY, trans., (Norwalk, 1953), p. 41. Nahum Kipnis has been one of the few scholars who has pointed out that the conventional interpretations had "oversimplified the response to Galvani's discovery by reducing it to the Galvani-Volta controversy". See KIPNIS, cit. 1, p. 109.

${ }^{9}$ I began this wide, complicated and long piece of research in my volume I fluidi della vita. In this paper I can simply resume and update some issues and conclusions to which this work had arrived. 
copies of the Commentarius arrived to Pavia, ${ }^{10}$ in Bologna a public polemic between galvanians and hallerians had already developed. It even seems that historians have not realized the importance of this event. Indeed, it was the first phase of the controversy (i.e. the controversy which took place within the community of physicians between those who defended the physiological ideas of Albrecht von Haller and those who had replaced irritability with animal electricity to explain the muscular movements). During almost the entire 1792 the observers of the time thought that this was the controversy on animal electricity.

The seventh volume of the Commentarii, which included Galvani's paper, was printed in the first days of January 1792. Giovanni Aldini, Galvani's nephew, had profited by the public anatomical ceremony which was held between the end of January and the beginning of February in the Archiginnasio Anatomical Theatre, to defend the "new animal electricity" against the "old animal spirits". Tarsizio Riviera Folesani, a hallerian anatomist and professor of medicine at the University of Bologna, was the adversary against whom Aldini launched his criticism.

In Pavia perhaps one of the most important groups of scientists in Europe was active in the late 18th century. And Pavia was the second stage of the controversy after Bologna. At the University of Pavia the feeling produced by Galvani's little Latin book, which became soon a best-seller, was enormous. Mariano Fontana wrote to the author:

Now with endless pleasure I tell you that the result of your finest experiments is considered an original discovery, that the experiments have been repeated and found very exact $[. .$.$] . In short, here now all is animal electricity, and your name is famous in$ Pavia. 11

Many scientists immediately began to repeat Galvani's experiments with frogs. The physicians were the fastest, because of the medical implications that the theory suggested. Eusebio Valli was the first author to publish a little paper on animal electricity, and he wrote that "Galvani's discovery" had prevented him "to sleep during several nights". ${ }^{12}$ In the following months Valli became an unusual ambassador of animal electricity in Europe. He began to travel, to make public displays of the galvanian experiments and to publish galvanian papers in many cities: first in Turin, ${ }^{13}$ then in Paris, ${ }^{14}$ and finally in London. Here in 1793 he

\footnotetext{
${ }^{10}$ Four copies of Galvani's masterpiece arrived in Pavia and they were received by Fontana, Carminati, Spallanzani and Malacarne. It is impossible that Galvani had sent a copy of the Commentarius to Volta, as claimed by FULTON and CUSHING, cit. 4, p. 244, because both Carminati and Volta admitted that Carminati had given his copy to Volta.

${ }^{11}$ L. BARBIERI, "La scoperta dell'elettricità animale nella corrispondenza inedita fra Luigi Galvani e Lazzaro Spallanzani, con due lettere di Mariano Fontana e Bartolomeo Ferrari”, Atti e memorie della deputazione di storia patria per l'Emilia e la Romagna, 3 (1937-8), pp. 70-1.

12 E. VALLI, Lettere sull'elettricità animale ad un suo amico, (Torino, 1792), p. 3.

${ }^{13}$ See the previous footnote.
} 
published a large English volume of 300 pages that has been forgotten by today's historians, even if at the time it constituted the most organic analysis of all the problems of galvanism. Naturally its title was Experiments on Animal Electricity. ${ }^{15}$

After Valli, Volta also decided to be interested in the scientific novelty of that moment. At the beginning Volta was suspicious, but after having repeated the experiments, in his first paper on the topic he confessed that "he converted himself" and that "he had changed from incredulity to fanaticism". ${ }^{16}$ In March 1792 Volta started with Bassiano Carminati a research program that brought to a complete upsetting of Galvani's paradigm. Also Volta was a galvanian, like everyone at that moment, even if he looked at the frog more as an electrical engine than an animal. For this reason he had started to make crossed experiments between the two Leyden jars - the condenser and the frog - to understand if the two electricities could be added up or be subtracted. In the "Memoria prima sull'elettricità animale" he wrote:

What is it possible to do well, in physics particularly, if things are not reduced to degrees and measures? ${ }^{17}$

On the other hand, Galvani followed a biological view, and on May 8, 1792, he wrote to Carminati:

It seems likely that there must be a difference of nature between them [i.e. the two Leyden jars], because of some change or preparation and alteration that the common electricity has received from the animal engine. ${ }^{18}$

When, in the Summer and Autumn of 1792, Volta published in Brugnatelli's Giornale fisico-medico and Amoretti's Opuscoli scelti sulle scienze e le arti some papers containing a new interpretation of the galvanian experiments based on the principle of electric action generated by metallic contact, ${ }^{19}$ the Italian scientific community had been compelled to choose between two opposite theories and two famous scientists. At the beginning everyone was galvanian. But it is not true, as is usually said, that all the physicians and biologists chose Galvani and that all the

${ }^{14}$ Valli published nine "Lettres sur l'électricité animale" in the Observations sur la physique of 1792 and 1793. See W. BERNARDI, "L'électricité animale: Les savants italiens et leurs relations avec les milieux français à la fin du XVIIIe siècle", in Échanges d'influences scientifiques et techniques entre pays européens de 1780 à 1830, (Paris, 1990), pp. 161-70.

${ }^{15}$ E. VAlli, Experiments on Animal Electricity with their Application to Physiology and some Pathological and Medical Observations, (London, 1793).

${ }^{16}$ A. VOLTA, “Memoria prima sull'elettricità animale”, VO, I, pp. 15-35, on p. 26.

${ }^{17}$ Ibid., p. 27.

${ }^{18}$ L. Galvani, "Lettera del chiarissimo Sig. Dottore Luigi Galvani al Sig. Prof. Don Bassiano Carminati”, Giornale fisico-medico, (1792):2, p. 142.

${ }^{19}$ See Volta, "Memoria seconda sull'elettricità animale", VO, I, pp. 43-74; "Memoria terza sull'elettricità animale", ibid., pp. 151-9; "Sull'elettricità animale ed alcune nuove proprietà del fluido elettrico", Giornale fisico-medico, (1972):2, pp. 287-90, also (with important changes) in Opuscoli scelti sulle scienze e sulle arti, 15 (1792), pp. 213-5; "Nuove osservazioni sull'elettricità animale comunicate dal Sig. Cav. D. Alessandro Volta", VO, pp. 145-7. 
physicists chose Volta. For instance Spallanzani chose galvanism, but some anatomists and physicians like Scarpa, Carminati, Mangili and Baronio chose the voltian theory. ${ }^{20}$ On the other hand, some physicists and mathematicians such as Sebastiano Canterzani, Anton Maria Vassalli and Volta's associate in the chair of physics at the University of Pavia, Carlo Barletti, always remained galvanians. ${ }^{21}$

Spallanzani was one of the most important and famous scientists in Pavia who chose to take side with Galvani against Volta. Previously he agreed with hallerian physiology, but when he read the Commentarius he was immediately convinced by Galvani's "numerous and various experiments" that animal electricity was the natural replacement for irritability. ${ }^{22}$ In the developing controversy Spallanzani always stayed with Galvani, and, with his friends Mariano Fontana, Barletti, Malacarne and Rezia, he led a group of fierce enemies of Volta in the University of Pavia.

Almost all the historians of the controversy on animal electricity have stated that Spallanzani was the author of the Transunto of Galvani's masterpiece published in Amoretti's Opuscoli scelti with the initial "S.". ${ }^{23}$ This mistake, which the historians passed on from one to another, has been dragging on too long now. The true author of the Transunto was Francesco Soave, the co-editor of the Opuscoli scelti, who used to put his initial "S." on his papers. This ascription has been definitely proved by a letter from Aldini to Venturi dated May 8, 1792, which I have found at the Municipal Library of Reggio Emilia. In the letter Aldini wrote:

The abstract of Galvani's paper is in printing in Milan now. It is being done by Father Soave, but this is not enough to satisfy public curiosity! A whole reprint is necessary. ${ }^{24}$

${ }^{20}$ Giuseppe Mangili had been one of Spallanzani's pupils at Pavia. Nevertheless he soon chose "the constant law of the different electric armatures". See MANGILI's manuscript entitled Miscellanea Mangili at the Municipal Library of Bergamo, 79. R.6.1-2, p. 32r. Carminati made the same choice. Already at the beginning of his experiments, in a letter to Galvani dated April 3, 1792, he called Volta "one of the best judges" that he knew "in those things". See B. CARMINATI, "Lettera del Signor Don Bassano [sic] Carminati diretta al Chiarissimo Sig. Dottore Galvani dell'Istituto di Bologna", Giornale fisico-medico, (1792):2, p. 116.

${ }^{21}$ Barletti wrote that "the most true and original" discovery of Galvani should resist all the attacks of "the visionaries", as he called Volta. Manuscript letter to Sebastiano Canterzani of June 30, 1793, Bologna, University Library, Letters to Sebastiano Canterzani, Ms. 2096, busta I.

${ }^{22}$ Letter to Galvani dated May-June 1794, in SPALlanZANI, cit. 6, V, p. 43.

23 "Transunto della dissertazione del Sig. Dott. Luigi Galvani P. Prof. nell’Università di Bologna sulle forze dell'elettricità ne' moti muscolari", Opuscoli scelti sulle scienze e sulle arti, 15 (1792), pp. 113-41. The awarding had been proposed by FULTON and CUSHING, cit. 4, pp. 244, 255; and reaffirmed by J.F. FULTON and M. STANTON, "A Bibliography of Galvani's Writings on Animal Electricity", in GALVANI, cit. 8, pp. 159, 169.

${ }^{24}$ Reggio Emilia, Municipal library “A. Panizzi”, Venturi Fund, Mss. Regg. A.13/11. The reprint of Galvani's Commentarius was published in Modena in the Summer of 1792 by Aldini with the close assistance of Giambattista Venturi. See L. GALVANI, De viribus electricitatis in motu 
Spallanzani always remained a galvanian. But there were other scientists who changed their ideas on animal electricity, though it is not true that everyone became voltian at the end of the controversy. Nor does the view that all the scientists who switched their allegiance should be shifted from Galvani's to Volta's party coincide with the historical data. Giambattista Venturi and Giovacchino Carradori made this choice, but others left Galvani for Volta in 1792 and afterwards they went back to animal electricity in 1794, when in the Trattato dell'uso e dell'attività dell'arco conduttore Galvani carried out his third experiment, with which he caused the muscular movements of the frogs without metals, simply by putting in contact the nerves and the muscles. ${ }^{25}$

The chemist and journalist Valentino Brugnatelli was an example of this event. At the beginning he was galvanian, later he became voltian, again galvanian and at the end, after the invention of the electric pile, voltian. ${ }^{26}$ Carradori is another example. In 1792 he stated against Galvani that the muscular movements were controlled by a nervous force. Later he chose galvanism, and only after the invention of the battery did he shift to Volta. ${ }^{27}$

musculari Commentarius cum Joannis Aldini dissertationes et notis. Accesserunt epistolae ad animalis electricitatis theoriam pertinentes, (Mutinae, 1792).

${ }_{25}$ See L. GAlvani, Opere scelte, G. BARBENSI, ed., (Torino, 1967), pp. 395-6. The news of Galvani's third experiment caused a general shock in the voltian party. The feeling was increased by the rumour, which only later proved unfounded, that in the month of December 1794 Valli had met Volta in Pavia and had "converted" him. For further details on this episode, which is still now unknown to historians, see BERNARDI, cit. 7, pp. 156-8.

${ }^{26}$ In his scientific reviews Giornale fisico-medico and Annali di chimica Brugnatelli published nearly all the papers on animal electricity by Volta, Giulio, Rossi, Carradori, Fontana, Fabbroni, Floriano Caldani, Valli and Aldini. In 1794 Brugnatelli announced "the ruinous downfall of Galvani's theory" because of the "repeated attacks of a terrible adversary" like Volta. See E. VALLI, "Lettera del Sig. Dott. Eusebio Valli al Sig. Brugnatelli sull'elettricità animale", Annali di chimica, 7 (1795), pp. 47-8. On the contrary, after the third experiment by Galvani, Brugnatelli attested that he had obtained the movements of the frog "without the help of the metals". See V. BRUGNATELLI, "Articolo di lettera di L. Brugnatelli al Signor Eusebio Valli M.D. sull'elettricità animale", Annali di chimica, 7 (1795), p. 250. Seemingly it was Aldini to convert Brugnatelli to animal electricity for the second time. See G. ALDINI, Essai théorique et expérimental sur le Galvanisme, avec une série d'expériences faites en présence des Commissaires de l'Institut national de France, et en divers amphithéâtres anatomiques de Londres, (Paris, 1804), pp. 13-4. About the experiments made by Brugnatelli with the electric battery in Pavia see his letters to Volta and Landriani of the year 1800 , in $V O$, II, pp. 3,8 .

${ }^{27}$ Carradori published many papers on galvanism and he also wrote a history of the controversy between Galvani and Volta. See G. CARRADORI, Lettere sopra l'elettricità animale scritte al Sig. Cav. Felice Fontana, (Firenze, 1793); Istoria del galvanismo in Italia o sia della contesa fra Volta e Galvani e decisione ricavata dai fatti esposti dai due partiti, (Firenze, 1817). I have republished all his works on galvanism: see G. CARRADORI, Scritti sull'elettricità animale, W. BERNARDI, introd. and notes, (Prato, 1989). The Istoria had been produced anonymously at an academic competition on galvanism published in 1805 by the Società italiana delle scienze. Besides Carradori, Volta himself had been one of the three candidates who took part in the competition. His paper was 
But, beside Galvani's and Volta's supporters, in Italy there were many who refused to take sides with one of the two leaders. This means that in the controversy there were not only two possible positions (i.e. Volta's and Galvani's), but at least three, four or five. Each theory explained the galvanian phenomena in a different way. Each theory had its supporters, its tradition, its university and geographical location in 18th-century Italy.

In the Spring of 1792 the picture of the controversy looked very different in Italy from that which it was to have some months later when Volta renounced animal electricity. At this moment Pavia, like Bologna, seemed the true fortress of galvanism. On the contrary Padua was the city where the galvanian theory met the strongest criticism. Indeed at the University of Padua there was a very active group of hallerian anatomists and physiologists. They were Leopoldo and his nephew Floriano Caldani, Stefano Gallini, Giuseppe Olivi and Simone Stratico. In hallerian physiology, muscular movements were produced by an internal force which was specific to muscular fibre: a mechanical force, different from life and from the nervous system, and which operated beyond consciousness. This function was active also in the muscular movements of dead and dissected animals when the fibres were touched by a metal knife or when a spark from a condenser was discharged on them. The electricity operated only as a stimulus of irritability, and it was irritability which was the one, true cause of the contractions.

The first feeling that Leopoldo Caldani had on reading Galvani's Commentarius was that it was not a revolutionary work, as many people said, but only a new expression of things and problems which had been already examined and refused in the hallerian controversy of the mid-18th century. Caldani himself had set right the technique for "preparing" the frog, which was to give renown to Galvani thirty years later. Indeed he had experimented that the discharge of the smallest quantity of electricity on the nerve moved the muscles of frog's legs also when all the external stimuli appeared to be ineffective because of the dryness of the nerves and of the distance of the death of the animal. In Caldani's opinion the galvanian experiment was new from the point of view of the technique, but not of the theory. Extending the number of occasional causes which aroused the irritability of the muscles was the only issue of this technique. The electricity was simply assimilated to the mechanical stimulus of the knife, to the chemical stimulus of the acids, and to the nervous stimulus of the "animal spirits" in the case of the muscular movements of living organisms. ${ }^{28}$

published in 1814 by Pietro Configliachi with the title Sull'identità del fluido elettrico col cosi detto fluido galvanico. See VO, II, pp. 205-99. In his history of the controversy between Galvani, Aldini and Volta, Carradori proclaimed Volta's victory with these words: "Aldini has no shelter; Volta has beaten him from all sides and, as everyone can see, the controversy is settled in favour of Volta" (Istoria, p. 64).

${ }^{28}$ L.M.A. CALDANI, "Sull'insensitività ed irritabilità di alcune parti degli animali. Lettera scritta al chiarissimo e celebratissimo Signore Alberto Haller", in G.B. FABRI, Sulla insensitività ed 
Against the physiologists like Tommaso Laghi, who assimilated electricity with "animal spirits", Caldani had used an argument in the 1750s that he considered still efficacious against Galvani. Since the electricity was the consequence of an automatic balance between two different electric poles put in contact, it seemed impossibleto provide the nervous fluid with "the necessary knowledge to send the electricity into one nerve rather than into another". For Caldani the "animal spirits" - if it was by them that the nervous sensibility operated - did not follow "the laws of the electric matter". The will could not "exempt this electric matter from the laws of balance to take the path of only one of the nerves which came out of the brain". For this reason nervous and muscular physiology did not operate by electricity. ${ }^{29}$

Caldani considered galvanism a return to a solution which had been rejected by Haller in the mid-18th century. In his opinion the controversy on animal electricity was something already seen, which could not change his opinions. What he wrote to Felice Fontana on March 3, 1792 was meaningful:

As you have seen in the last volume of the Academy of Bologna, we come back to electricity; but how electricity obeys the will of the soul will always be an inexplicable problem. $^{30}$

Perhaps Caldani did not repeat the galvanian experiments himself. But since his nephew worked with him at the University of Padua, he encouraged him to do this. So Floriano Caldani repeated the galvanian experiments with Gallini and Stratico, and in 1792 he published the results in a paper entitled Experiments on Animal Electricity. It was the official reply of the hallerians to Galvani. Floriano Caldani stated that, after the experiments with the metallic arc, nobody could question the existence of electricity in the animal; but there were many doubts that it was animal electricity. Nevertheless, this "really new" discovery was not doomed to produce in physiology and in medicine the "total revolution" produced by the hallerian theory. Floriano Caldani did not deny the existence of a physical electricity in living bodies, but he did not attribute to it any physiological function. He considered physical electricity only a stimulus which exited "the irritability of the muscular fibre". ${ }^{31}$

Now it is interesting to consider how Floriano Caldani viewed the first interventions of Volta in the controversy, particularly in the "Memoria seconda" published in the Giornale fisico-medico of June and July 1792. In Caldani's opinion Volta was surely a galvanian, because he stated, unlike what he would defend later,

irritabilità halleriana. Opuscoli di vari autori raccolti da Giacinto Bartolomeo Fabri, (Bologna, 1757), I, pp. 331-2.

29 L.M.A. CALDANI, letter to Felice Fontana of March 30, 1792, in F. FONTANA, Carteggio con Leopoldo Marc'Antonio Caldani 1758-1794, R.G. MAZzOLINI and G. ONGARO, eds., (Trento, 1980), pp. 331-2.

${ }^{30}$ Ibid., p. 330.

${ }^{31}$ F. CALDANI, Riflessioni sopra alcuni punti di un nuovo sistema de' vasi assorbenti ed esperienze sulla elettricità animale, (Padova, 1792), pp. 113, 144, 157-8. 
that the electric arc could not produce or move the electricity. Galvani and Volta disagreed about the place and the direction of the electricity which caused the muscular movements of the frog, but this seemed a plurality of solutions inside the same theory based on animal electricity. Volta's paper, however, included also two experimental novelties which immediately attracted Caldani's attention. In Caldani's opinion Volta did not seem to glimpse the new theory of the metallic electricity, as it appears to us. This fact was absolutely invisible to the readers of the time. On the other hand Caldani was interested in an experiment that seemed to be a great menace to animal electricity. Indeed Volta was successful in moving the muscles of the frog also closing the electric circuit over the nerve alone. From this he had deduced that the "animal spirits" could not have an electric nature, because the electricity caused by the galvanian stimulus did not arrive at the muscles. Caldani and Volta seemed to agree upon a tactical alliance against Galvani, because both refused the galvanian claim that animal electricity was the only cause of muscular physiology.

In Volta's same paper there was another experiment which Caldani immediately supported. The discovery that the heart and other involuntary muscles, which possessed great irritability, were not sensitive to electrical stimulus caused by the electric arc. A discovery which had been soon criticised by Fontana in Florence, Scarpa in Pavia, Carlo Giulio and Francesco Rossi in Turin, who asserted that the frog's heart regularly contracted being put between two metals. ${ }^{32}$ On the contrary, in the hallerians' opinion both the heart and those animals lacking a nervous system, such as the molluscs, were not sensitive to electricity. For them, these examples finally proved that the theory of irritability was valid even after Galvani's experiments. ${ }^{33}$

If at the beginning of the controversy the hallerians of Padua had considered Volta a possible ally in their war against Galvani, later they were not likewise interested. Indeed, to decide if the electricity was moved "in the animal itself or in the metals" was a very secondary problem. In any case, either it was animal electricity or metallic electricity, this did not concern the physiology of living bodies for which the cause of the movement was irritability. ${ }^{34}$

The hallerians paid some attention to Volta. On the other hand, they started a strong attack against the galvanians, chiefly when Galvani's nephew, Giovanni

32 See F. FontanA, "Articolo di lettera del Sig. Cav. F. Fontana all'Ab. Giuseppe Mangili", Giornale fisico-medico, (1792):4, pp. 116-8; C. GIULIO and F. ROSSI, "Estratto di alcune sperienze fatte da' Signori Dr. Carlo Giulio e Francesco Rossi le quali dimostrano essere i movimenti del cuore di animali di sangue caldo e di sangue freddo eccitabili, facendo comunicare le armature metalliche applicate a' nervi, che si diffondono nella di lui sostanza, col cuore medesimo per mezzo d'arco metallico", Giornale fisico-medico, (1793):1, pp. 82-7.

${ }^{33}$ See F. CALDANI, Osservazioni sulla membrana del timpano e nuove ricerche sulla elettricità animale lette nell'Accademia di scienze, lettere ed arti di Padova, (Padova, 1794), pp. 92-3, 119.

${ }^{34}$ See F. Caldani, "Lettera del Medesimo [Sig. Floriano Caldani] al Sig. Ab. Giuseppe Olivi", Annali di chimica, 7 (1795), pp. 168-9. 
Aldini, became the leader of the galvanian party. Indeed, Aldini and Floriano Caldani were the protagonists in a sort of "war of the two nephews", which represents the second aspect of the controversy on animal electricity in Italy. It goes without saying that the controversy between hallerians and galvanians (i.e. the medical and biological side of the controversy on animal electricity) was completely eliminated by Volta's triumph and appear nearly invisible to the historians who consider the history of science from the point of view of those who won in the competition for the discovery of truth.

The problem of the heart movements of the frog put between two different metals, which seemed to be favourable to the hallerians, was discussed by the great anatomist Antonio Scarpa, who offered to Volta a disciplinary knowledge which he surely lacked. If the hallerians said that the heart had no nerves, or it had no nerves of movement, in his anatomical masterpiece entitled Tabulae neurologicae ad investigandam historiam anatomicam cardiacorum nervorum Scarpa stated that the heart, like every organic part, was endowed with specific sensibility. This property had to be attributed to the heart even if it was not possible to view by the microscope the nerves entering directly into the cardiac muscle, because the vitalistic and antihallerian physiology which Scarpa defended imposed that every muscular fibre was sensitive. This discovery was greeted with joy by the galvanian Valli, who wrote:

Now the hallerian [sic] cannot say any more: the heart has no nerves. The famous Scarpa has taken by storm their terrible fortress, behind which they obstinately defended themselves. $^{35}$

It was an illusion. If it was true that Scarpa's anatomical discoveries played against the hallerians, this did not mean that they were favourable to animal electricity. And Scarpa stated that the cause of the movements of the frog's heart was "the electrical torrent pushed by the contact of the metals", as had been proved by "our illustrious Physics Professor Alessandro Volta". ${ }^{36}$

In the 18th-century medical tradition there was another way of declaring oneself anti-galvanian. In Tuscany this solution was defended by some vitalistic scientists like Fontana and Carradori at the Museum of Natural History of Florence, or Francesco and Leopoldo Vaccà Berlinghieri at the University of Pisa. These naturalists stated that in galvanian phenomena the operating force had not an electric but a vital nature. It was a nervous fluid which ran through the nerves to the muscles. This fluid was the true effective cause of the muscular movements, and not the occasional cause of the physiology as the hallerians claimed. ${ }^{37}$

\footnotetext{
35 E. VALLI, "Lettera del Dott. Eusebio Valli al Signor Aldini”, Giornale fisico-medico, (1795):1, pp. 264-5.

36 A. SCARPA, Tabulae neurologicae ad investigandam historiam anatomicam cardiacorum nervorum, noni nervorum cerebri, glossopharyingaei et pharyngaei ex octavo cerebri, (Ticini, 1794), p. 6.

${ }^{37}$ See F. VACCÀ BERLINGHIERI, Idee di fisiologia medica presentate a' suoi scolari, (Pisa, 1795),
} 
A third theory, which was opposed to Galvani and Volta and also to the different biological solutions of the hallerians and of the vitalists, was defended by another Florentine scientist, Giovanni Fabbroni. As early as 1792 he suggested a chemical interpretation of galvanism which advanced the solution proposed by Anthony Carlisle, William Nicholson and Humphry Davy in the early 19th century. ${ }^{38}$ But, because of an unusual sequence of publishing misfortunes, all Fabbroni's attempts to take part in the debate between Galvani and Volta failed. Indeed, on August 21, 1793, he read another paper on galvanism at the Florentine Accademia dei Georgofili, which however was published only in 1801, when the controversy on animal electricity had already ended. ${ }^{39}$ In the meantime two translations of the same essay, a French one and an English one, had been published in Jean-Claude De La Métherie's Journal de physique and in William Nicholson's Journal of Natural Philosophy. Unfortunately, they attracted little or no attention before the invention of the electric battery by Volta. ${ }^{40}$ The same welcome had been given also to a miscellaneous letter, dated November 11, 1793, that Fabbroni published in the Giornale fisico-medico, where he briefly advocated that "the action of the different thin sheets over the senses" was caused by "a true and pure chemical operation". ${ }^{41}$

Fabbroni had a specifically chemical training, and so he had considered with much interest Volta's curious experiment by which he discovered that two different metals put in contact over the tongue produced acid and alkaline tastes analogous to those produced by a little electric spark. This phenomenon had been interpreted by Volta as a demonstration of the electric power of the metals, according to his contact

pp. 73-88. In 1792 and 1793 Francesco's son, Leopoldo Vaccà Berlinghieri, published two important French papers, by which he informed the Parisian scientists of the galvanian experiments that had been made in Pisa. See L. VACCA BERLINGHIERI, "Extrait d'une lettre de M. Léopold Vaccà Berlinghieri à J.C. Delamétherie, sur l'électricité animale, and suite des expériences sur l'électricité animale: Extrait du bulletin de la Société philomatique", Observations sur la physique, 41 (1792), pp. 314-6; 42 (1793), pp. 289-91.

${ }^{38}$ The first expression of this view is in a paper addressed by Fabbroni to Brugnatelli, which was not published in the Giornale fisico-medico. A manuscript copy of this important article, till now unknown, is in a letter of Fabbroni's son, Leopoldo Pelli Fabbroni, to Arthur de la Rive of January 5, 1857. See Copie d'une lettre écrite par Fabbroni à Brugnatelli, Geneva, Bibliothèque publique et universitaire, Ms. Fr. 2318, pp. 274r-275r.

${ }^{39}$ G. FABBRONI, "Dell'azione chimica dei metalli nuovamente avvertita", Atti della Reale società economica di Firenze, ossia dei Georgofili, 4 (1801), pp. 349-70.

${ }^{40}$ G. FABBRONI, "Sur l'action chimique des différens métaux entr'eux, à la température commune de l'atmosphère, et sur l'explication de quelques phénomènes galvaniques", Journal de physique, 49 (1799), pp. 348-57; "On the Chemical Action of Different Metals on Each Other at the Common Temperature of the Atmosphere", Journal of Natural Philosophy, Chemistry and the Arts, 3 (1799), pp. 300-10; 4 (1800), pp. 120-7. The same article was published also in the Philosophical Magazine, 5 (1799), pp. 268-71.

${ }^{41}$ G. FABBRONI, “Articolo di lettera del Signor Gio. Fabbroni al Signor Brugnatelli”, Giornale fisico-medico, (1793):4, p. 146. 
and non-chemical theory of electricity, but Fabbroni stated that there was a true chemical action caused by the oxidation of the metals. He wrote:

It seemed to me clear that the different metals, which are in state of solidity and at the common temperature, were liable to exercise a chemical action because of their mutual contact, with the intervention of humidity. ${ }^{42}$

A fourth theory, which was irreducible to the positions of both Galvani and Volta, was the interpretation of the galvanian phenomena proposed by dowsers. Carlo Amoretti and Pierre Thouvenel, a French naturalist who was travelling through Italy at this time, eagerly accepted Galvani's discovery, because it seemed to prove their ideas. According to the dowsers, there were people, such as Thouvenel's famous companion Joseph Pennet, who felt the presence of underground metals and waters with their divining rod, and for this reason they could be considered true "electrometers" like Galvani's frog. Thouvenel said that his discovery of "mineral electricity" and Galvani's discovery of animal electricity were two discoveries destined "to mark a new epoch". Indeed they seemed "to explain each other and to confirm mutually", because they were ruled by the same "fundamental principles". In spite of the dowsers' hopes, neither the galvanians nor the voltians answered Thouvenel's and Amoretti's invitations, and so the theory of "mineral electricity" was considered nothing but an imposture. ${ }^{43}$

In 18th-century Italy the controversy on animal electricity did not concern Galvani and Volta only. As we have seen, many other scientists took part in the debate, defending different interpretations and solutions which could not be

42 FABBRONI, cit, 39, p. 354. On Fabbroni's role in the controversy on animal electricity see F. ABBRI, "Il misterioso 'spiritus salis': Le ricerche di elettrochimica nella Toscana napoleonica", Nuncius. Annali di storia della scienza, 2 (1987), pp. 55-88, and BERNARDI, cit. 7, pp. 288-301. The best, complete work on Fabbroni is now R. PASTA, Scienza politica e rivoluzione: L'opera di Giovanni Fabbroni (1752-1822) intellettuale e funzionario al servizio dei Lorena, (Firenze, 1989). 43 P. THOUVEnel, Lettera al Sig. Abate Amoretti intorno l'elettricità animale. This manuscript letter, dated August 15, 1792, is preserved at the Istituto Lombardo di Scienze e Lettere in Milan. During his stay in Italy Thouvenel published two large volumes about dowsing. See P. THOUVENEL, Recueil de Mémoires concernant l'électricité organique et l'électricité minérale: D'après des expériences faites en Italie et dans les Alpes depuis 1789 jusqu'en 1792, (Brescia, 1792); and La guerra di dieci anni: Raccolta polemico-fisica sull'elettrometria galvano-organica. Parte italiana-parte francese, (Verona, 1802). AMORETTI published a "Breve storia del galvanismo" in the Opuscoli scelti sulle scienze e le arti, 22 (1803), pp. 357-82, and later a volume entitled Della raddomanzia ossia elettrometria animale. Ricerche fisiche e storiche, (Milano, 1808). He wrote about the relationship between dowsing and Galvani's and Volta's theories: "Dowsing seemed forgotten when in Bologna the dead, halved frog jumped under the eyes of Galvani, who, being a learned and ingenious professor of Physics, considered the phenomenon worthy of his research. [...]. And all of a sudden, as a big fire lights from a spark, galvanism occupied the laboratories and schools; later it extended to the Academies and tried to play a part in the Hippocratic art itself, when the famous Volta enormously increased the action of the electromotors with his most ingenious machines" (Della raddomanzia, pp. 396-7). 
assimilated to the theories of animal and metallic electricity. Though many of these authors have been neglected till now by the historians, they were true protagonists of the controversy on galvanism. We should come back to study their papers and manuscripts, if we want to recover a more complete and more realistic picture of Italian and European science in the late 18th century. 